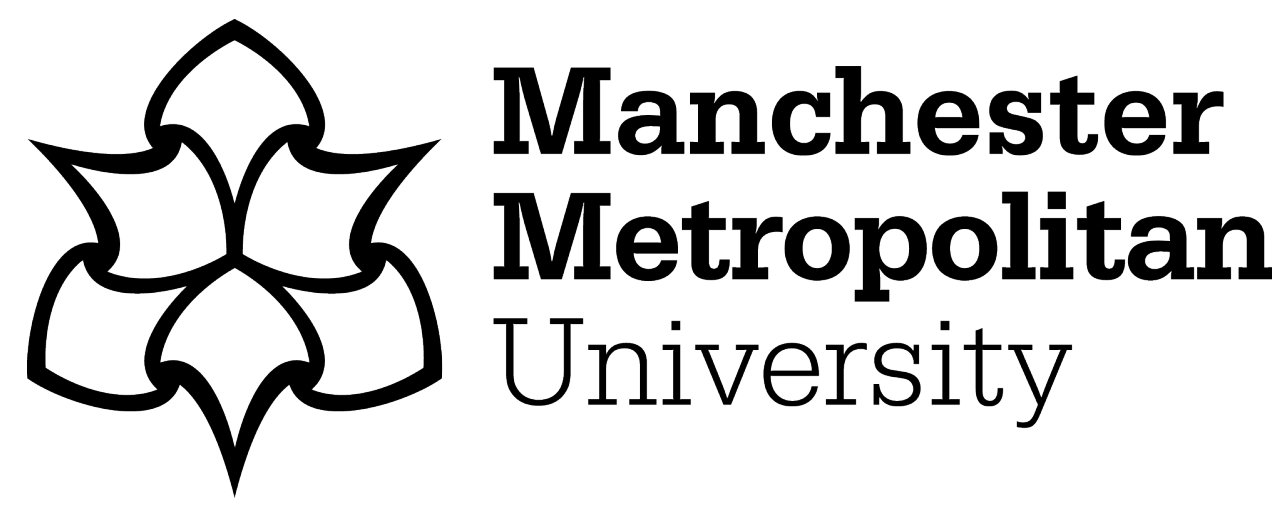

Albertson, K (2014) Markets, privatisation and law and order - some economic considerations: Kevin Albertson discusses the difficulty of aligning private incentives with the public good. Criminal Justice Matters, 97 (1). pp. 4-5. ISSN 0962-7251

Downloaded from: https://e-space.mmu.ac.uk/621367/

Version: Accepted Version

Publisher: Taylor \& Francis (Routledge)

DOI: https://doi.org/10.1080/09627251.2014.950507

Please cite the published version 


\section{Markets, Privatisation and Law and Order - Some economic considerations}

\section{Kevin Albertson discusses the difficulty of aligning private incentives with the public good.}

In the following, we discuss the social efficiency of delivering criminal justice from the point of view of the neo-liberal economic paradigm. We do not seek either to critique or support the basic principles of neo-liberalism; rather, we consider, if we chose to accept the neoliberal discourse, how might the provision of criminal justice be carried out most effectively and in line with social wellbeing.

Neo-liberalism has many meanings, but here we adopt common usage as a description of a body of theory which, in accordance with Friedman (1962), suggests governments adopt policies broadly promoting a circumscribed role for the state and economic and social policies informed/determined by the operation of individual incentive structures in (supposedly) free-markets.

\section{The theory of markets}

\section{The roles of individuals and corporations}

The neo-liberal paradigm is based on the principles of individuals' pursuit of self-interest and the corporate sector's maximisation of shareholder returns (Friedman 1962: 113). It is suggested such self-interest, coordinated through the market, will lead to efficiency - the best possible outcome for a given unit of resource.

The reason why markets are, in theory, efficient is that, where good value for consumers' money is supplied, the supplier may expect payment and repeat trade. Conversely, if the consumer fails to receive that for which they are prepared to pay, they will either not pay or will change suppliers. Similarly, the asking price serves to align customers' expectations with production costs. Therefore, in order to compete, suppliers produce that which the consumer requires at a reasonable price. In this sense, free-markets provide an evolutionary process, moulding trade through millions of individual choices to motivate consumers and suppliers to engage in efficient exchange (Beinhocker 2006).

The power of a market economy is illustrated by Paul Seabright in recounting the perplexity of a former communist Russian official who asked "who is in charge of the supply of bread to the population of London?" Seabright (2004: 10). In a market economy, according to Seabright, "nobody is in charge". Leaving it to individuals to decide what is in their own interest is more efficient than trying to work out, centrally, what it is those millions desire. 


\section{The roles of the state}

There is, however, a curious paradox in market-based systems. Although markets are a more efficient means of coordinating human activity in the provision of goods and services than a centrally planned economy, without regulation, markets are liable to provide goods and services inefficiently from a social point of view. If Seabright's official had asked, "who is in charge of the purity of the bread in London?", or, for that matter, "who is in charge of ensuring that beef lasagne in London contains only beef?", perhaps the answer might not have been "nobody".

For markets to work efficiently at a social level, there must be full information on costs and outcomes, and rapid and direct feedback from consumers to suppliers. While it is generally the case that, for example, consumers can tell a good loaf of bread from a poor loaf, it is clearly more difficult to tell beef from horse in a processed meat product. Where the level of information and feedback is poor, suppliers' profits may be enhanced by deceiving the consumer. The less information is available to the consumer and the fewer the opportunities for feedback, the greater is the potential for market inefficiency.

The neo-liberal policy prescription in such a situation is for citizens is to utilise the power of the state to create an incentive structure so that the pursuit of individual and corporate profit will lead to maximised social wellbeing (Friedman 1962: 112). Thus, neo-liberal state exists "to preserve law and order, to enforce private contracts, to foster competitive markets" (ibid.: 11). A further role of government is to pursue social goals as "government may enable us at times to accomplish jointly what we would find it more difficult or expensive to accomplish severally" (ibid.).

In short, an individual's pursuit of self-interest will not necessarily lead to maximised social prosperity unless the "invisible hand" of the market is constrained by the rest of us through the state (c.f. Friedman 1962: 31).

\section{The provision of law and order}

\section{Social efficiency}

While it is the state's responsibility to provide law and order, neo-liberalism does not prescribe whether such provision should be directly by publically owned enterprises or through contracted agents. However, when considering such contracting, the question of the relative efficiency of the private and public sectors must be framed in such a way which reflects overall social benefit. For instance, historically it has been the case that a decline in employment and/or wages is observed in publicly-owned industries after privatisation (Haskel and Szymanski 1993). Whether or not this reflects an increase in efficiency may depend on the metric employed. The public decision maker has a responsibility to consider 
the level of direct costs and services delivered, but must also take into account external effects, such as the impact of direct cost savings on unemployment and the impact on taxes and benefits, on society as whole.

\section{Targets}

Whether law and order is provided directly by the state, or whether it is contracted out, its efficient provision relies on market principles. The ultimate customer is society; the supplier is either government or its contracted agent. In practice, it is not straightforward for citizens to determine whether the required amount of criminal justice has been delivered. Justice is not easily quantified and statistics are notoriously difficult to interpret, even where they are accurate. Society may therefore come to rely on rather blunt indicators, for example a reduction in proven reoffending. This motivates the whole concept of Payment by Results (Fox and Albertson 2011), where society empowers the state efficiently to deliver performance targets as proxies for criminal justice.

However, the adoption of targets as a substitute for effectively operating markets has been shown to lead to inefficiency and "corruption pressures" (Campbell 1976: 34). The market will deliver the most efficient way of hitting any target, whether or not this target accurately reflects the matter of interest to the customer (ibid.). Ultimately, it is perceptions of safety and levels of crime which society seeks to address through criminal justice - such qualitative policy goals may prove difficult, if not impossible, to reflect in a simple quantitative measure. Any indicator which becomes a target can not then be used as an indicator.

\section{Localism}

Empowering local government through devolution of state power is a second general thrust of neo-liberal policy (Friedman 1962:11). In whatever they ask of the state, the feedback process from consumers to government will theoretically be more effective at the local level. Citizens are generally more knowledgeable about their locale than about the nation as a whole; local preferences may differ from those of the nation; and there is a greater chance voters will have more experience in judging competence and performance of a local elected politician compared to a centrally designated minister.

In the UK, we have recently elected Police and Crime Commissioners, PCCs, responsible at local level for law and order provision. By construction, voting for a PCC is informed by voters' local perspectives on crime, whereas voting patterns in national elections will be informed by a variety of issues. Therefore, neo-liberal theory suggests, if PPCs were given the power to contract for criminal justice, their focussed mandate should facilitate customer feedback and increase the efficiency of provision. 


\section{Transparency}

To maximise the information content of criminal justice expenditure and provision - further to facilitate informed voter behaviour, and therefore increase efficiency - all criminal justice expenditure and associated statistics and interpretation ought to be publically and clearly available. If the market is to work effectively, the customer must be able to determine whether they have received the service for which they have paid. Similarly, to minimise the potential for distortion of criminal justice targets, society might monitor criminal justice provision through the establishment of a means of bringing any such distortions to the attention of the public at large.

\section{In sum}

Free-markets are by no means adequate to align reasonable social goals, such as the provision of criminal justice services, with the pursuit of corporate profits. Moreover, socio-political and regulatory mechanisms by which the two might be aligned are by no means straightforward. In general, we suggest neo-liberal theory indicates criminal justice contracts are most likely to be aligned with community aspirations where:

1. The social benefits of public provision are accurately compared to the social benefits of private sector provision;

2. Contracts are negotiated and delivered at the local level by community representatives, democratically elected, with direct local accountability;

3. So far as possible, contracts reflect holistic social goals, rather than simplistic targets;

4. Contracts are clear and transparent, and the terms and conditions are freely available so citizens can provide feedback through democratic processes;

5. Facilities are made available, informally and formally, for the performance of elected representatives and criminal justice contractors' performance to be monitored by citizens in real-time time.

Ultimately, it must be borne in mind, markets work best when they are: simple; open; and amenable to effective regulation.

\section{Kevin Albertson is a Reader in Economics at Manchester Metropolitan University.}

\section{References}

Beinhocker, E.D. (2006) The Origin of Wealth, Harvard Business School Press, Boston.

Campbell, D. T. (1976) Assessing the Impact of Planned Social Change, paper\#8, Occasional 
paper series, The Public Affairs Centre, Dartmouth College. Reprinted (2011) Journal of MultiDisciplinary Evaluation, 7(15), 3-43.

Fox, C., and Albertson, K. (2011) Payment by Results and Social Impact Bonds in the Criminal Justice Sector: New challenges for the concept of evidence-based policy?, Criminology \& Criminal Justice, 11(5) 395-413.

Friedman, M. (1962) Capitalism and Freedom, Chicago: University of Chicago Press.

Haskel, J., and Szymanski, S. (1993) Privatization, liberalization, wages and employment: theory and evidence for the UK, Economica, 161-181.

Seabright, P. (2004) The Company of Strangers: A Natural History of Economic Life, Princeton University Press. 